\title{
Characterization of the porcine $C D K N 3$ gene as a potential candidate for congenital splay leg in piglets
}

\author{
Steffen MAAK ${ }^{\mathrm{a} *}$, Simone JAESERT ${ }^{\mathrm{a}}$, Karsten NEUMANN ${ }^{\mathrm{b}}$, \\ Gerhard vON LENGERKEN ${ }^{\mathrm{a}}$ \\ ${ }^{a}$ Institute of Animal Breeding and Husbandry with Veterinary Clinic, \\ Martin-Luther-University Halle-Wittenberg, Adam-Kuckhoff-Str. 35, \\ 06108 Halle, Germany \\ ${ }^{\mathrm{b}}$ Institute of Zoology, Martin-Luther-University Halle-Wittenberg, \\ Domplatz 4, 06108 Halle, Germany
}

(Accepted 26 February 2003)

\begin{abstract}
Congenital splay leg is a hereditary disease observed in newborn piglets. The etiology and pathogenetic mechanism of the disorder are still unknown. The gene for cyclindependent protein kinase inhibitor $3(C D K N 3)$ was identified as a potential candidate gene in a differential display experiment. We analyzed the gene on sequence variations and compared its expression in $M$. biceps femoris between healthy and affected piglets. Comparative sequencing of the coding region of three healthy and four splay leg piglets revealed twelve single nucleotide polymorphisms (SNP) resulting in six amino acid exchanges in the deduced sequences. However, all polymorphisms were observed in healthy as well as in splay leg piglets thus excluding structural differences of the gene as a cause of the disease. Besides full length transcripts, we found a variety of aberrantly transcribed cDNA in clones derived from $M$. biceps femoris of healthy as well as of splay leg piglets. All alternative transcripts coexist with normal cDNA. Expression analysis revealed a trend towards higher values in M. biceps femoris of splay leg piglets supporting the results obtained from a differential display.
\end{abstract}

CDKN3 gene / expression analysis / congenital splay leg / piglet

\section{INTRODUCTION}

Splay leg in newborn piglets was first recognized as a hereditary disorder by Thurley et al. [19]. A sex-affected inheritance of the disorder is assumed since higher frequencies have been observed in male piglets than in female piglets $[7,15]$. A monogenic hereditary path could be excluded by statistical analyses although the existence of one or more major genes for congenital splay

* Correspondence and reprints

E-mail: maak@landw.uni-halle.de 
leg seems possible [16]. Affected piglets are characterized by an obvious weakness of the hind limbs immediately after birth leading to impaired mobility [1]. Consequently, losses among splay leg piglets amount to $15-50 \%[6,17,21]$. Despite intensive research, the pathological basis of the disease is still poorly understood. Several biochemical and histo-morphological investigations indicate an immaturity of the skeletal muscle in the affected piglets at birth $[1,2$, $5,14]$. We have recently reported the isolation of skeletal muscle EST differentially expressed in M. biceps femoris of healthy and affected piglets [9-12]. Among the fragments strongly displayed in the splay leg muscle, we identified the porcine $C D K N 3$ (cyclin-dependent kinase inhibitor 3) gene [13]. CDKN3 belongs to a family of dual-specificity protein phosphatases and is involved in cell cycling [3,4]. Mutations of $C D K N 3$ as well as overexpression and aberrant transcripts are related to delayed cell cycle progression and carcinogenesis in humans, respectively $[3,8,22]$. Because of the physiological function of the gene product and the observed variability of gene expression in human tissues, we investigated the porcine $C D K N 3$ gene as a potential candidate for splay leg in piglets.

\section{MATERIALS AND METHODS}

\subsection{Origin of samples}

Total RNA was prepared from M. biceps femoris of twenty-eight piglets (fourteen splay leg piglets and fourteen healthy controls) immediately after birth by $\mathrm{CsCl}$ centrifugation and stored at $-80^{\circ} \mathrm{C}$ until further processing. From these samples, seven were randomly chosen (four splay leg, three controls) and comparatively sequenced. The remaining twenty-one samples (ten splay leg and eleven controls) were analyzed on expression differences. These samples were derived from eleven males and ten females and almost evenly distributed in both experimental groups. All animals were sampled on a single commercial farm within three weeks. The healthy controls were unrelated to the splay leg piglets. However, the relationships within both experimental groups are unknown.

\subsection{Sequence analysis}

The $p C D K N 3$ cDNA was synthesized as described elsewhere [12]. For the amplification of the coding region of the porcine $C D K N 3$ gene, the following primer sets were used:

CdknF: 5'GTG AGA CTG CCA GCC ATG AAG3';

CdknR: 5'TTG ATG ATA GAT GTG CAG CTA ATT T3';

KAP3F: 5'ATC GAC AGC CTG AGA GAC C3';

KAP3R: 5'TTG CCA ATA AAA GCT TTA GGA A3'. 
The PCR products were cloned into the pGEM-T vector (Promega) and both strands were sequenced on an automated sequencer (ALFexpress, Amersham Biosciences). Sequence alignments were performed with the DNASIS software (v2.1, Hitachi).

\subsection{Analysis of gene expression}

The comparative analysis of CDKN3 expression was done with a PCRELISA test (Roche) essentially as described by the manufacturer and Van den Hemel-Groten et al. [20]. Briefly, a $307 \mathrm{bp}$ fragment of the $p C D K N 3$ cDNA was amplified with the following primers:

\section{Cdkn3F: $\quad$ 5'GGT TTA TGT GCT CTT CCA GGT TGT A3'; Cdkn3R: 5'TCC CAA GTC CTC CGT AAC AGT GTA T3'.}

In a first step, the range of quantitative (linear) amplification was determined by reducing the cycle number gradually starting with 40 cycles. The internally DIG-labeled PCR product was then bound to the streptavidin coated surface of a microplate by use of a biotin-labeled, gene specific capture probe (Cdkn3CAP: 5'BioGCT CCT GAC ATA GCC AGC TGC TGT G3'). The bound, DIGlabeled PCR products were detected with an anti-DIG-peroxidase conjugate and the substrate ABTS. The colorimetric signal allows semi-quantitative determination of the amount of PCR product. A fragment of the $\beta$-actin gene was amplified in a separate reaction for each sample and used as the external standard (primers: ActinF: 5'GGG CAG GTC ATC ACC ATC GGC AA3'; ActinR: 5'GTC CCG CCA GAC AGC ACC GTG TT3'; capture probe; ActinCAP: 5'CTA CAG AGG CGG GGG CGG GC3'). The values for individual $C D K N 3$ expression are given as the ratio between the absorbance units for $C D K N 3$ and $\beta$-actin, respectively.

Additionally, we analyzed the gene expression by Real-time PCR (ABI PRISM 7000 Sequence Detection System, Applied Biosystems). For this experiment, we used the primer pairs for $C D K N 3$ and $\beta$-actin described above. The fluorescent dye SybrGreen ${ }^{\circledR}$ was used for detection of the PCR products. For both genes, standard curves were calculated from dilution series and each individual sample was normalized to the standards. Again, the obtained normalized values for $C D K N 3$ expression were given as a ratio to the individual, normalized $\beta$-actin expression. The statistical analysis was performed with the General Linear Model option of the Statistica software (v6.0, StatSoft Inc.). The fixed effects health status (splay leg, control) and sex were included in the model to analyze the variables birthweight and expression of $\beta$-actin and CDKN3 with PCR-ELISA and Real-time PCR, respectively. 


\section{RESULTS}

\subsection{Comparative sequencing of the coding region of the porcine CDKN3 gene}

The initial sequencing of the cDNA in four piglets revealed only one polymorphism in a poly(A) stretch of the 3'-untranslated region of the gene [13]. In order to detect potential differences on DNA and protein level, the coding region of the $p C D K N 3$ gene was sequenced in four healthy and three splay leg piglets. Sequence differences were found at twelve nucleotide positions which would lead to six amino acid substitutions in the deduced sequence (Fig. 1). All observed SNP are located in the exons 2, 3, 4 and 5, whereas the sequences of exons 1, 6, 7 and 8 were completely identical in all investigated animals. However, none of the observed SNP were exclusively found in either healthy or splay leg piglets. Moreover, sequence analysis revealed the occurrence of aberrant transcripts in healthy as well as in affected piglets. In three out of four investigated splay leg samples and in one out of three control samples, we found a total of six cDNA with either deletions of partial or complete exons or insertions of intronic sequences. All of the aberrant transcripts coexist with full length transcripts. A conceptual translation of the sequences (Fig. 2) demonstrated that the deletions observed in two splay leg samples (tr1a and $\operatorname{tr} 2$ ) result in deletions of complete amino acid blocks from an otherwise normal amino acid sequence. In all other cases the deletions/insertions led to premature stop codons and/or significant changes of the deduced amino acid sequences. In 5 out of 6 transcripts the catalytic core motif (HCXXXXGR) of the enzyme was altered or deleted.

\subsection{Expression of the porcine CDKN3 gene in M. biceps femoris of healthy and splay leg piglets}

Gene expression was investigated in skeletal muscle samples of healthy and affected piglets of both genders. The birth weights of all groups did not differ significantly thus excluding a bias caused by this trait. Furthermore, no effect of the factor "sex" was observed on any of the expression data obtained with PCR-ELISA and Real-time PCR, respectively. The range of linear amplification was between PCR cycles 21 and 24 for $\beta$-actin as derived from PCR-ELISA and Real-time PCR analyses. This confirmed the results of Te Pas et al. [18] obtained with comparable reaction conditions. The corresponding cycle numbers for $C D K N 3$ were 31 and 33, indicating the existence of fewer amounts of $C D K N 3$ mRNA in the muscle samples compared to $\beta$-actin mRNA. Furthermore, the standard curves as well as the melting curve analysis confirmed the generation of a single, specific PCR product for $\beta$-actin and $C D K N 3$ under the applied reaction conditions, respectively. 
Table I. Birthweight and expression of $\beta$-actin and CDKN3 in M. biceps femoris of healthy and splay leg piglets (LSM $\pm \mathrm{SE}$ ) measured with PCR-ELISA and Real-time PCR. The values are comparable only within a method and for a single gene.

\begin{tabular}{|c|c|c|c|c|c|c|c|c|}
\hline Group & $\mathrm{N}$ & $\begin{array}{c}\text { Birth- } \\
\text { weight } \\
\text { (grams) }\end{array}$ & $\begin{array}{l}\beta \text {-Actin } \\
\text { (a) }\end{array}$ & $\begin{array}{l}\text { PCR- } \\
\text { ELISA } \\
C D K N 3 \\
\text { (b) }\end{array}$ & $\begin{array}{l}\text { Ratio } \\
\text { (b/a) }\end{array}$ & $\begin{array}{l}\beta \text {-Actin } \\
\text { (c) }\end{array}$ & $\begin{array}{c}\text { Real- } \\
\text { time } \\
\text { PCR } \\
C D K N 3 \\
\text { (d) }\end{array}$ & $\begin{array}{l}\text { Ratio } \\
(\mathrm{d} / \mathrm{c})\end{array}$ \\
\hline Control & 11 & $\begin{array}{l}1.132 \\
\pm 76\end{array}$ & $\begin{array}{c}0.130 \\
\pm 0.017\end{array}$ & $\begin{array}{c}0.161 \\
\pm 0.018\end{array}$ & $\begin{array}{c}1.541 \\
\pm 0.381\end{array}$ & $\begin{array}{c}0.361 \\
\pm 0.050\end{array}$ & $\begin{array}{c}0.354 \\
\pm 0.073\end{array}$ & $\begin{array}{l}1.087 \\
\pm 0.177\end{array}$ \\
\hline Splay leg & 10 & $\begin{array}{l}1.235 \\
\pm 79\end{array}$ & $\begin{array}{c}0.087 \\
\pm 0.018\end{array}$ & $\begin{array}{c}0.191 \\
\pm 0.019\end{array}$ & $\begin{array}{c}2.672 \\
\pm 0.398\end{array}$ & $\begin{array}{c}0.314 \\
\pm 0.052 \\
\end{array}$ & $\begin{array}{c}0.417 \\
\pm 0.076\end{array}$ & $\begin{array}{c}1.382 \\
\pm 0.185\end{array}$ \\
\hline$P$-value & & 0.36 & 0.10 & 0.26 & 0.06 & 0.53 & 0.56 & 0.26 \\
\hline
\end{tabular}

With PCR-ELISA, a statistically non-significant trend towards lower $\beta$-actin and higher $C D K N 3$ gene expression was observed in splay leg piglets (Tab. I). This could be confirmed by Real-time PCR and was in accordance with the more intense fragment observed in the differential display experiment for $C D K N 3$ [10]. The calculated relative CDKN3 gene expression (related to the individual $\beta$-actin expression values) was slightly higher in the splay leg piglets compared to the healthy ones (Tab. I).

\section{DISCUSSION}

The hereditary disorder "splay leg in newborn piglets" is suspected to be caused by a delayed maturation of limb muscles $[1,2]$ although final proof is still lacking. Thus, a potential involvement of factors related to cellular development and differentiation can be assumed. We analyzed one of these factors derived from a previous Differential Display/Reverse Transcriptase experiment [9] on its relation to congenital splay leg on the structural as well as on the expression level. Mutations in the cyclin-dependent kinase inhibitor 3 (CDKN3) gene were shown to have an impact on the development of several human cell types. The detected SNP in the porcine $C D K N 3$ gene however, were not related to congenital slay leg in piglets. None of the SNP were located within or in close vicinity to the nucleotides coding for the catalytic active site, respectively. Whether the amino acid changes have any functional impact on the function of the enzyme remains unclear. Therefore, we can exclude single nucleotide polymorphisms in this gene as the primary cause for the disease. We observed a total of six aberrant transcripts of the CDKN3 gene in our limited sample of three healthy and four affected piglets. All but one of the observed 
transcripts resulted in a destruction or a deletion of the catalytic active site suggesting a loss of function of the enzyme. Investigations on human cancerous and healthy liver tissue have revealed the occurrence of aberrant transcripts of $C D K N 3$ in fourteen out of twenty-seven cancerous samples and two control samples [22]. The alterations are comprised of deletions of complete exons, frame shift mutations as well as premature stop codons. Functional analyses demonstrated the inactivity of most of the derived products [22]. Although, in our study no variant was found that is identical with the human transcripts, all described types of aberrations were observed in the porcine samples, too. The coexistence of full length with aberrant transcripts in our samples was also noticed in all investigated human samples. Yeh et al. [22] assume a competition mechanism between the wild type and aberrant transcripts. Lee et al. [8] demonstrated an increased expression of the $C D K N 3$ gene in breast and prostate cancer. This overexpression results in a dysregulation of the cell cycle by an unknown mechanism. Direct behavior as an oncogene cannot be excluded although the coexpression of $C D K N 3$ and specific oncogenes seems possible. The comparative analysis of $C D K N 3$ expression in healthy and splay leg piglets revealed no significant differences. The observed trend towards higher values in splay leg muscle was reproducible with two independent assays and furthermore, supported by the initial results of the differential display. However, a general overexpression of $C D K N 3$ can be ruled out as the primary cause for congenital splay leg based on our data. Since the PCR primers used for the expression studies are both located in exon 8 , no differentiation between the expression of full length and variant transcripts is possible. Therefore, further experiments should include more animals and the generation of transcript specific hybridization probes analysis allowing the separate quantification of each type of transcript. In our experiment we could detect several SNP and aberrant transcripts of the porcine CDKN3 gene. The expression of the gene was not significantly affected in splay leg piglets. Whereas the SNP alleles are not related to the splay leg syndrome, the role of transcriptional aberrations of the gene in the pathogenesis deserves further investigations.

\section{ACKNOWLEDGEMENTS}

This work was supported in part by Deutsche Forschungsgemeinschaft (grant No. MA 2002/7-1). The expert technical assistance of Gerda Becke is gratefully acknowledged.

\section{REFERENCES}

[1] Bergmann V., Elektronenmikroskopische Befunde an der Skelettmuskulatur von neugeborenen Ferkeln mit Grätschstellung, Arch. Exp. Vet. Med. 30 (1976) 239-260. 
[2] Deutsch K., Done J.T., Congenital myofibrillar hypoplasia of piglets: ultrastructure of affected fibres, Res. Vet. Sci. 12 (1971) 176-184.

[3] Gyuris J., Golemis E., Chertkov H., Brent R., Cdi1, a human G1 and S phase protein phosphatase that associates with Cdk2, Cell. 75 (1993) 791-803.

[4] Hannon G.J., Casso D., Beach D., KAP: a dual specificity phosphatase that interacts with cyclin-dependent kinases, Proc. Natl. Acad. Sci. USA 91 (1994) 1731-1735.

[5] Hillert S., Kolb E., Büchner A., Untersuchungen über den Gehalt an DNA, RNA, Protein und Nicht-Protein-N in Geweben von normal entwickelten Ferkeln sowie von Grätschferkeln sehr unterschiedlicher Geburtsmasse (1.Mitteilung), Arch. Exp. Vet. Med. 41 (1987) 65-77.

[6] Hörügel K., Lorenz A., Untersuchungen zum angeborenen Beinspreizen bei Ferkeln in einer industriemäßig produzierenden Zuchtanlage, Mh. Vet.-Med. 34 (1979) 183-184.

[7] Lax T., Hereditary splayleg in pigs, J. Hered. 62 (1971) 250-252.

[8] Lee S.W., Reimer C.L., Fang L., Iruela-Arispe M.L., Aaronson S.A., Overexpression of kinase-associated phosphatase (KAP) in breast and prostate cancer and inhibition of the transformed phenotype by antisense KAP expression, Mol. Cell. Biol. 20 (2000) 1723-1732.

[9] Maak S., Jaesert S., von Lengerken G., Identification of candidate genes for congenital splay leg in piglets - first results, Arch. Anim. Breeding 42 (1999) special issue 167-170.

[10] Maak S., Jaesert S., Neumann K., Yerle M., von Lengerken G., Isolation of potential candidate genes for congenital splay leg in piglets by Differential Display/Reverse Transcriptase PCR (DD/RT PCR), in: Proceedings of the 27th ISAG Conference, 20-26 July 2000, Minneapolis, p. 30.

[11] Maak S., Jaesert S., Neumann K., Yerle M., von Lengerken G., Rapid communication: Chromosomal localization and partial cDNA sequence of the porcine ATP synthase, $\mathrm{H}^{+}$transporting, mitochondrial F0 complex, subunit e (ATP5I) gene, J. Anim. Sci. 79 (2001) 1352-1353.

[12] Maak S., Jaesert S., Neumann K., Yerle M., von Lengerken G., Isolation of expressed sequence tags of skeletal muscle of neonatal piglets and mapping by somatic cell hybrid analysis, Anim. Genet. 32 (2001) 303-307.

[13] Maak S., Jaesert S., Neumann K., von Lengerken G., Rapid communication: Nucleotide sequence and physical mapping of the porcine cyclin-dependent kinase inhibitor 3 (CDKN3) gene, J. Anim. Sci. 80 (2002) 1698-1699.

[14] Prange H., Maak S., Geipel U., Investigations on congenital splayleg syndrome in newborn piglets, in: Proceedings of the 34th Annual Meeting of the GVMS "Physiology and Pathology of Reproduction", 22-23 February 2001, Giessen, p. 34.

[15] Sellier P., Ollivier O., Étude génétique du syndrome de l'abduction des membres (splay leg) chez le porcelet nouveau-né. Modèle multifactoriel à un seuil, Ann. Génét. Sél. Anim. 14 (1982) 77-92.

[16] Stigler J., Distl O., Kruff B., Kräusslich H., Segregationsanalyse von Erbfehlern beim Schwein, Züchtungskunde 63 (1991) 294-305. 
[17] Svendsen L.S., Weström B.R., Svendsen J., Olsson A.C., Karlsson B.W., Blood serum characteristics of newborn pigs: Comparison of unaffected pigs with pigs belonging to five mortality groups, Acta Vet. Scand. 32 (1991) 287-299.

[18] Te Pas M.F.W., Verburg F.J., Gerritsen C.L.M., de Greef K.H., Messenger ribonucleic acid expression of the $M y o D$ gene family in muscle tissue at slaughter in relation to selection for porcine growth rate, J. Anim. Sci. 79 (2000) 69-77.

[19] Thurley D.C., Gilbert F.R., Done J.T., Congenital splayleg of piglets-myofibrillar hypoplasia, Vet. Record 80 (1967) 302-304.

[20] van den Hemel-Grooten H.N., Te Pas M.F., van den Bosch T.J., Garssen G.J., Schreurs V.V., Verstegen M.W., mRNA levels of the calpain system in longissimus muscle of young pigs during prolonged feeding of a protein-free diet, J. Anim. Sci. 75 (1997) 968-974.

[21] Wrathall A.E., The boar and congenital problems, Pig Vet. Soc. Proc. 21 (1988) 116-134.

[22] Yeh C.T., Lu S.C., Chen T.C., Peng C.Y., Liaw Y.F., Aberrant transcripts of the cyclin-dependent kinase-associated protein phosphatase in hepatocellular carcinoma, Cancer Res. 60 (2000) 4697-4700.

To access this journal online: www.edpsciences.org 